\title{
背もたれの高さが安楽座位における 臀部ずれ力に及ぼす影響
}

\section{Effect of Height of Backrest on the Shear Force on the Buttocks in Comfortable Sitting}

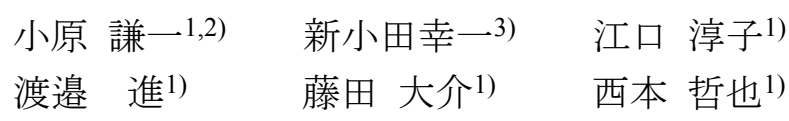

KENICHI KOBARA ${ }^{1,2)}$, KOICHI SHINKODA ${ }^{3)}$, ATSUKO EGUCHI ${ }^{1)}$, SUSUMU WATANABE ${ }^{1)}$, DAISUKE FUJITA ${ }^{1)}$, TETSUYA NISHIMOTO ${ }^{1)}$

1) Department of Rehabilitation, Faculty of Health Science and Technology, Kawasaki University of Medical Welfare: 288 Matsushima, Kurashiki, Okayama 701-0193, Japan. TEL +81 86-462-1111

2) Doctoral Program, Hiroshima University Graduate School of Health Sciences

3) Department of Physical Therapy and Occupational Sciences, Hiroshima University Graduate School of Health Sciences

Rigakuryoho Kagaku 23(3): 403-406, 2008. Submitted Nov. 22, 2007. Accepted Jan. 16, 2008.

ABSTRACT: [Purpose] The purpose of this study was to consider the effect of the height of a backrest on shear force on the buttocks in comfortable sitting. [Subjects] Thirteen healthy adult men (age: $21.3 \pm 2.4$ ) participated in the study. [Methods] We measured the shear force on the buttocks in sitting using a force plate. Considering morphological effects, the measure of shear force after eliminating the body weight of each subject was adopted. The measuring position was the long sitting position with the buttocks on the force plate and lower legs outside the force plate. Instead of a backrest, parallel bars were used which were set laterally not to touch the force plate. The experiment was conducted under two conditions by adjusting the height of the backrest (46 and $49 \mathrm{~cm}$ from the floor). [Results] The shear force with the backrest height of $46 \mathrm{~cm}$ from the floor was $0.8 \pm 0.27[\mathrm{~N} / \mathrm{kg}]$, and at $49 \mathrm{~cm}$ from the floor it was 0.71 $\pm 0.25[\mathrm{~N} / \mathrm{kg}$ ], showing a significant difference between two conditions $(\mathrm{p}=0.014)$. [Conclusion] The result suggests that when the height of backrest is high, the shear force on the buttocks is small.

Key words: height of backrest, comfortable sitting, shear force on buttocks

要旨：〔目的〕本研究は, 背もたれの高さが安楽座位時の臀部ずれ力に及ぼす影響を検討することを目的として行っ

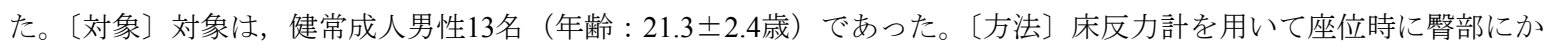
かるずれ力を測定した。形態学的な影響を考慮し, 測定したずれ力を各対象者の体重で除した值を採用した。測定肢 位は, 床反力計上に殿部, 床反力計外に下肢を置いた長座位とした。背もたれの代わりとして床反力計上に接しない ように横方向に設置した平行棒にもたれさせた。実験は，背もたれ（平行棒）の高さを調節した2条件（床面から46 $\mathrm{cm}$ と $49 \mathrm{~cm}$ ) で行った。〔結果〕結果を背もたれ高別にみると， $46 \mathrm{~cm}$ では $0.83 \pm 0.27[\mathrm{~N} / \mathrm{kg}], 49 \mathrm{~cm}$ では0.71 $0.25[\mathrm{~N} /$ $\mathrm{kg}$ ]であり，2条件間に有意差が認められた $(\mathrm{p}=0.014)$ 。結語〕本研究結果から，背もたれの高さが高い方が臀部ずれ 力は小さくなることが示された。

キーワード : 背もたれ高, 安楽座位, 臀部ずれ力

1)川崎医療福祉大学＼cjkstart医療技術学部リハビリテーション学科：岡山県倉敷市松島288（テ701-0193） TEL 086-462-1111

2) 広島大学大学院 保健学研究科博士課程後期

3) 広島大学大学院 保健学研究科

受付日 2007年11月22日 受理日 2008年1月16日 


\section{I. はじめに}

座位は, 運動学的には臥位から立位への中間的な姿 勢である1)。また，立位と比較すると座位姿勢は，(1)支 持面が広く, 安定性があり, (2)下肢への体重負荷が少な く, (3)エネルギー消費量が少ないなどの有利な点が挙げ られる1)。したがって, 座位は, 食事や排泄, 入浴や休 息など, 日常生活を送る際に非常に多くの時間を過ごす 姿勢となる。また, 脳卒中片麻痺患者や春髄損傷患者な ごの下肢に何らかの障害を持つ人は，1日の中で椅子座 位を取る時間が健常者と比較すると非常に長い。加え て, 最近では,「寝たきり」を防ぐために長時間椅子上 に座らされている「座らせきり」がみられ，それらの人 は座位姿勢を自ら変化させることが難しい。そのため, 背もたれにもたれることによって支持基底面を広げ,坐 骨部周囲の不快な圧迫を軽減させている2)。背もたれに もたれ, 安楽に座っている際にも慰部にはずれ力は生じ ているが3)，慰部の皮膚と座面との摩擦によって骨盤部 に著明な位置のずれはみられない。そのずれ力と摩擦力 は筋などの軟部組織の変形を引き起こしており, その変 形が生体内の骨や軟部組織の境界部に複雑な深層応力 を生じさせ, 毛細血管の閉塞を引き起こしている。近年 ではこのずれ力が, 圧迫力と併せて皮膚表面に働くこと によって発生する生体内部の複雑な応力のメカニズム が解明されてきており ${ }^{4}$, 裖瘡予防を目的としてずれ力 について検討することの臨床的意義は強いと思われる。

椅子の背もたれと臀部ずれ力の関係について, Bush ら5) は背もたれの後傾角度が変化している間に慰部ず れ力は有意に増加すると述べており, Gilsdorf ら 6 は, 車いすの背もたれを最も後傾させた位置( 水平面との 角度 $58^{\circ}$ ) から最も起こした位置（水平面との角度 $5^{\circ}$ ) まで起こすことで，慰部ずれ力はクッション上の座位 で約9 $[\mathrm{kg}]$ 増加したと報告している。また, Goosens ら 7$)$ は車い寸座位における臂部ずれ力を測定し, 縦方向で $4.8[\mathrm{kPa}]$, 横方向では $8.5[\mathrm{kPa}]$ であったと報告してい る。さらに Hobson $^{8)}$ は, 12 名の脊髄損傷者と 10 名の健 常者を対象にして車いすの背もたれをリクライニング した際の背もたれと座面の力を測定し, 研究者や臨床 家は，障害を負った人々の座位姿勢に注意を払う必要 があると述べている。我々は先行研究にて, 我々が提 案する実験モデル3）用いて椅子座位における慰部ず れ力を推定し, 背もたれと骨盤の位置関係や普通型車 い寸のシートのたわみが慰部ずれ力に与える影響につ いて報告してきた9,10)。それらの結果から，背もたれの 高さが能部ずれ力に影響する可能性が示唆された。し
かしながら，上述のように，背もたれの角度による影 響を検討した報告 $5,6,8)$ はいくつか見られるが，高さを 変えて慰部ずれ力を実際に測定し検討した報告は, 我々 が涉猟する限りにおいては見当たらない。そこで本研 究は, 背もたれの高さが慰部ずれ力に与える影響を検 討することを目的として行った。

\section{II. 方 法}

\section{1. 対象}

対象は, 下肢・体幹に疾患のない健常成人男性 13 名 (年齢 : $21.3 \pm 2.4$ 歳, 身長 : $174.7 \pm 5.3 \mathrm{~cm}$, 体重 : $67.1 \pm$ $8.6 \mathrm{~kg})$ であった。各対象者には事前に本研究の概要を 文書にて説明した上で協力を求め, 了承を得た。

\section{2. 臀部ずれ力測定方法}

本研究は椅子座位を想定しているが，下肢の摩擦の 影響をできる限り除いて背もたれの高さの影響のみを 検討するために, 背もたれにもたれた長座位を安楽座位 として定義し, 両下腿部をローラー板（酒井医療社製 DYJOC BOAD，キャスター直径 : $40 \mathrm{~mm}$, 床面とロー ラーの摩擦係数 $\mu=0.1 ）$ 上に置いた。また, 脊柱後彎 の程度の影響や背もたれのクッション性, 背部との摩擦 の影響を除くために, 金属製の平行棒 (オージー技研社 製）の片側を背もたれとして使用し，各対象者には同一 の衣類を着用させた。なお，臂部にかかる力を正確に測 定するために, 平行棒は床反力計に接触させないように 横方向に設置した（図1）。

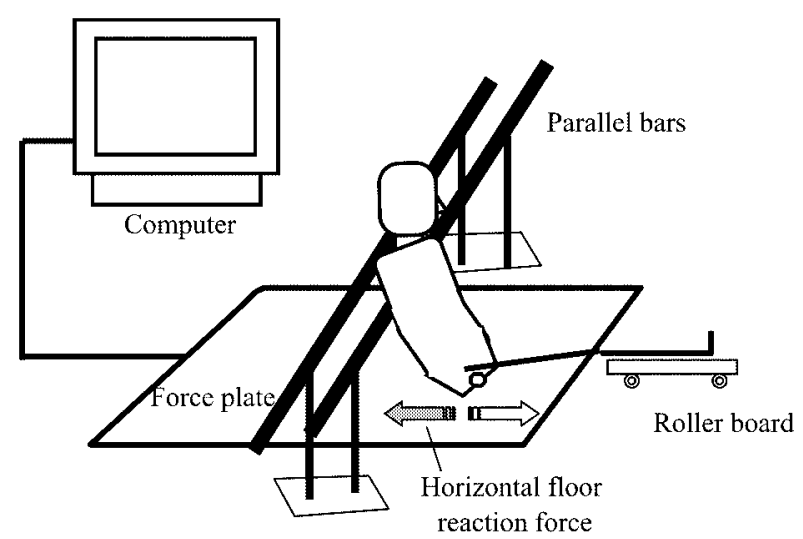

図1 測定概略図

床反力前後分力の後方向への反力を前方向へのずれ力として 算出した。 
安楽座位時の臀部にかかる力の測定には, 床反力計 （アニマ株式会社製FORCE PLATE MG-1120）を用い, サ ンプリング周波数は $100 \mathrm{~Hz}$ とした。安定した測定值を得 るために，測定はその測定肢位を 10 秒間保持した後に 開始した。床反力分力前後成分をもとに, 前方向へのず れ力を算出し，2秒間の測定のうち中間にあたる 1 秒間 （0.5〜 1.5 秒）における平均值を求めた。測定肢位は, 床 反力計上に殿部, 床反力計外に下肢を置いた長座位と し，身体の後方に設置した平行棒（以下，背もたれ）に もたれた肢位 (安楽座位) とした。その際の臀部の位置 は，体幹・骨盤前後傾中間位で背部が背もたれ部に軽く 触れるように座った（基本座位）時の大転子位置を基準 位置とし，そこから前方へ $5 \mathrm{~cm}$ 移動させた位置とした。 また, 両上肢はリラックスした状態で大腿部に置くよう に指示し, 頭䅡部は体幹後傾に伴う後傾位から立ち直つ た位置で，真っ直ぐ前を向くように指示した。実験は， 背もたれの高さを床面から $46 \mathrm{~cm}$ と $49 \mathrm{~cm}$ に調節した2条 件で行い, 統計学的解析では形態学的な影響を考慮し, 測定したずれ力を各対象者の体重で除した值を採用し た。

\section{3. 統計学的解析}

統計解析用ソフトウェアはSPSS for Windows version $14.0 \mathrm{~J}$ (エス・ピー・エス・エス・ジャパン社製）を用 いた。背もたれ高の2条件間での臀部ずれ力の比較には, paired t-testを用い, 危険率 $5 \%$ 未満をもって有意とした。

\section{III. 結 果}

床反力前後分力における後方への反力（前方への臀 部ずれ力）は，背もたれ高別にみると， $46 \mathrm{~cm}$ では 0.83 $\pm 0.27[\mathrm{~N} / \mathrm{kg}], 49 \mathrm{~cm}$ では $0.71 \pm 0.25[\mathrm{~N} / \mathrm{kg}]$ であり, 2 条件 間に有意な差が認められた $(\mathrm{p}=0.014)$ 。

\section{IV. 考 察}

あらゆる姿勢について, 良い姿勢, 悪い姿勢が存在す る。椅子座位において理想的な姿勢とは, 左右対称で, 骨盤はわずかに前方傾斜しており, 股関節・膝関節は90 度屈曲位で足底は中立位で全面接地であると言われて いる11)。しかしながら, 高齢者や何らかの障害を負った 人々が,このような理想的な椅子座位がとれるかどうか は疑問である。理想的な座位が得られれば，しっかりと した座面上で両側の坐骨結節で左右均等に荷重がなさ れ, 骨盤がやや前傾した腰部への負担の少ない姿勢が可
能となる ${ }^{12)}$ 。しかし, 理想的な姿勢とはいえ時間の経過 とともに徐々に苦痛を感じるようになり, 長時間座位を 持続するには坐骨結節部以外の部位でも荷重を行い, 圧 力分散と筋緊張のバランスを同時に保つ必要がある。そ の方法の一つとして,安楽に背もたれにもたれることが 挙げられるが, 最近では, 長時間の座位を強いられるこ とによって坐骨部に生じる裖瘡が問題となっている ${ }^{13)}$ 。 本研究は, 背もたれの高さが裖瘡との関連が注目されて いるずれ力に及ぼす影響を検討したものである。

本研究結果では，背もたれ高が高い方が臀部ずれ力 は有意に低值を示していた。この理由には, 背もたれと 背部の接点と上体である頭部節・頝部節・骨盤を含む体 幹節の合成質量中心 (Resultant Center of Mass: RCOM) 位 置との関係が考えられる。椅子上安楽座位における臀部 ずれ力発生のメカニズムについて, 廣瀬は, 骨盤後傾に 伴った体幹への背もたれからの反力が, 殿部や大腿部を 滑らせる力となると述べている14-17)。また, 我々は先行 研究 ${ }^{18)}$ にて, 圧力分布変化の時間的要素を検討すること で検証した。その結果, 背もたれにもたれた直後に座圧 分布が前方へと変位し始めていた。このことから，椅子 上安楽座位では, 背もたれにもたれるために骨盤を含む 上体を後傾させることより, 重心線が座圧中心点（座面 作用点）から逸脱するため, RCOM部には上体を後方 倒そうとする回転モーメントが生じており ${ }^{19)}$, その力は 背もたれにもたれると背もたれ接点に作用して体幹を 押し返す反力となって, それが安楽座位における臀部ず れ力発生の一つの要因となると報告している。

この臀部ずれ力発生のメカニズムを踏まえて, 上述 の背もたれ接点と 3 節のRCOM位置との関係について考 察する。我々の先行研究3)から, 本研究とほぼ同様の条 件（対象者の平均身長：172.5 $\pm 5.3 \mathrm{~cm}$ ) では, 坐骨結節 から $37.9 \pm 4.9 \mathrm{~cm}$ 後上方に体幹後傾に沿った位置に推定 することができる。したがって, 本研究で背もたれとし て使用した平行棒は, どちらの条件下においても, 各対 象者の3節のRCOM位置よりも高い位置に設置されたこ とになる。よって, 背もたれ高が高いほど背部との接点 はRCOM位置からより離れることから, 力点と作用点の 関係から背もたれ接点に作用する力はより小さくなる と推測される。それに伴い, 作用反作用の法則に従って 背もたれからの反力も小さくなったために, 臂部のずれ 力は減少したと考える（図2）。

背もたれ高が高いほど, 臀部ずれ力はある程度抑え ることができるという本研究の結果から, 裖瘡予防の観 点から長時間の座位をとる患者では, 使用する椅子や車 いすを考えるにあたり, 背もたれ高を十分に考慮する必 


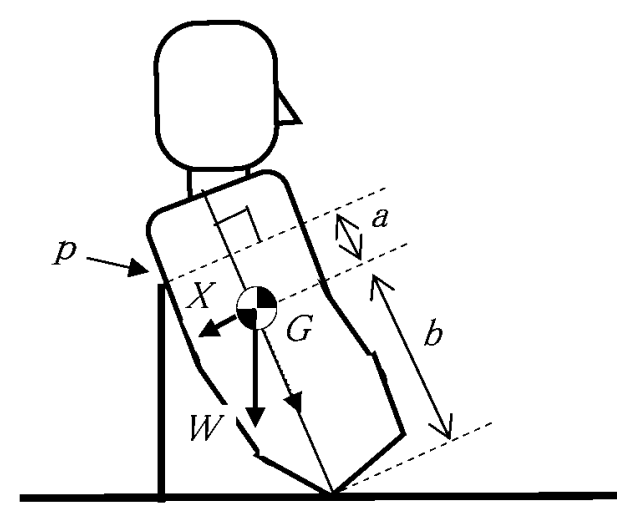

図2 合成質量中心と背もたれ接点との関係
$\mathrm{G}$ : 上体3節の合成質量中心（力点）
$\mathrm{p}$ : 背もたれと背部の接点 (作用点)
$\mathrm{a}$ ：背もたれ接点から合成質量中心までの長さ
b : 合成質量中心から坐骨結節までの長さ
W：骨盤を含む上体の体重
$X$ : 合成質量中心位置-坐骨線に直角なべクトル
(上体の後傾によって生じる力)

要性が明らかとなった。しかしながら, 臨床場面でよく 見かける椅子や車いすの背もたれは, 背もたれの高さの 影響のみを検討するために本研究で用いた平行棒とは 材質や形状が大きく異なるものである。また, 本研究で は下肢の摩擦の影響をなるべく少なくして統一するた めに, 長座位で下腿部をローラー板に載せた姿勢での測 定となっており, 実際の椅子座位とは実験条件が乘離し ている。したがって, 背もたれの形状や材質, さらに は, 対象者の体格に合わせた背もたれ高の差による臀部 ずれ力の検討が今後の課題として残される。

\section{引用文献}

1) 畠中泰司, 大川嗣雄, 伊藤利之 : 障害者といす. PTジャーナ ル, 1990, 24: 805-811.

2) Trefler E, Hobson DA, Taylor SJ, et al.: Seating and mobility for person with physical disabilities. Therapy Skill Builders, Memphis, 1993, pp3-5.
3) 小原謙一, 江口淳子, 石浦佑一・他 : 実験モデルによる安楽 座位におけるずれ力推定值の妥当性の検証. 理学療法学, 2007, 34(Suppl) : 511.

4) 大力博輝, 藤井幹康, 阿波啓造・他 : ズレ力による裖瘡発生 機構とその予防に関する研究. 日本機械学会2004年度年次大 会講演論文集 $(S 47-1$ 介護・福祉装置, S47 健康・福祉機器 の開発)，2004，4:217-218.

5) Bush TR, Hubbard RP: Support force measures of midsized men in seated positions. J Biomech Eng, 2007, 129: 58-65.

6) Gilsdorf P, Patterson R, Fisher S, et al.: Sitting forces and wheelchair mechanics. J Rehabil Res Dev, 1990, 27: 239-246.

7) Goossens RHM, Snijders CJ, Holscher TG, et al.: Shear stress measured on beds and wheelchairs. Scand J Rehab Med, 1997, 29: 131-136

8) Hobson DA: Comparative effects of posture on pressure and shear at the body-seat interface. J Rehabil Res Dev, 1992, 29:21-31.

9) Kobara K, Eguchi A, Watanabe S, et al.: Relationships between backrest of a chair and the position of pelvis on the estimated value of shear stress. Physiotherapy, 2007, 93(S1): S638.

10) 小原謙一, 江口淳子, 渡邊 進・他：普通型車いすシートの たわみが臀部ずれ力推定值に与える影響. 第4回広島保健学 学会学術集会抄録集, 2007, 23.

11) Jackson OL: Therapeutic consideration for the elderly. Churchill Livingstone, New York, 1987, pp93-111.

12）木之瀬隆，廣瀬秀行 : 座位姿勢の基本的な考え方とシーティ ングシステム一高齢者向けの座位保持装置一. OTジャーナ ル, 1996, 30:465-472.

13) 田中秀子 : 裖瘡一の看護介入とその効果, 座位時の体圧分散 用具の有効性はどこまで明らかにされているか. EB NURSING，2005， $5:$ 469-474.

14) 廣瀬秀行: 高齢座位生活者の裖瘡の特徵とその予防. MB Med Reha, 2004, 38 : 48-55.

15) 廣瀬秀行 : 高齢者のシーティング 2, 裖瘡予防に必要なシー ティング. OTジャーナル, 2004, 38 : 968-974.

16) 廣瀬秀行 : 生活支援における理学療法（士）の役割, 移動と 生活支援. 理学療法, 2004, 21 : 1265-1270.

17) 廣瀬秀行 : 裖瘡最前線, 発生予防のための除圧・減圧の具体 策. 総合リ八, 2004, 32: 523-528.

18) 小原謙一, 江口淳子, 藤田大介・他 : 椅子上安楽座位におけ るずれカ発生のメカニズム一座圧分布変位の時間的要素に よる検証一. 理学療法科学, 2007, 22 : 185-188.

19) 江原義弘, 山本澄子 : ボディダイナミクス入門, 歩き始めと 歩行の分析. 医歯薬出版, 東京, 2004, pp9-15. 